\title{
Recurrent seasonal occurrence of the Lineated Woodpecker (Dryocopus lineatus) in a riparian fragment of the Atlantic Forest, northeastern Brazil
}

\author{
Rafael Menezes ${ }^{1,4}$, Georgiana M. Pimentel ${ }^{1}$, Ricardo S. Rosa ${ }^{2}$ \& Alan Loures Ribeiro ${ }^{3}$ \\ Programa de Pós-graduação em Ciências Biológicas (Zoologia), Universidade Federal da Paraíba, Cidade Universitária, João Pessoa, PB, Brazil. \\ Departamento de Sistemática e Ecologia, Centro de Ciências Exatas e da Natureza, Universidade Federal da Paraíba, João Pessoa, PB, Brazil. \\ 3 Laboratório de Ornitologia, Departamento de Sistemática e Ecologia, Universidade Federal da Paraíba, Cidade Universitária, João Pessoa, PB, \\ Brazil. \\ 4 Corresponding author: rafaelmenez@gmail.com
}

Received on 28 July 2018. Accepted on 27 March 2019.

\begin{abstract}
Riparian forests play important roles as ecological corridors and refuge habitat for many bird populations in fragmented landscapes. This report describes the seasonal occurrence of the Lineated Woodpecker (Dryocopus lineatus) in a small riparian fragment of Atlantic Forest, northeastern Brazil. A female was recorded by its visual and acoustical signals from September to October 2014. Similar occurrences were observed in the same months over three consecutive years. Two major hypotheses regarding the woodpecker seasonal occurrence are discussed here: $i$ ) the use of the riparian fragment for breeding, evidenced by tree-cavity nests; and ii) fleeing of the bird from its natal habitat due to fire in adjacent sugarcane fields, which commonly are burned in these two months. Such recurrent events suggest that $D$. lineatus uses the riparian fragment as refuge habitat, highlighting the importance of these environments for bird populations that inhabit fragmented landscapes of the Brazilian Atlantic Forest.
\end{abstract}

KEY-WORDS: breeding, cavity-nesting birds, Picidae, refuge habitat, sugarcane burning.

\section{INTRODUCTION}

Riparian forests are interface zones between terrestrial and aquatic systems characterized by high nutrients cycling and flood-influenced seasonal resources (Naiman \& Décamps 1997). Birds use these environments as ecological corridors for crossing habitats and as refuge for feeding and breeding (Knopf \& Samson 1994). In Brazil, the riparian forests are essential for maintenance of bird fauna in fragmented environments (Anjos et al. 2007), hosting increased species richness in rivers with larger riparian margin width (Ramos \& Anjos 2014).

The Brazilian Atlantic Forest is recognized as one of the major biodiversity hotspots around the world (Myers et al. 2000). Historically, the domain has largely been reduced to fragmented landscapes as a result from human-disturbances, with only $11.7 \%$ of its original coverage remaining (Ribeiro et al. 2009). Despite highly fragmented, the northeastern region of the Atlantic Forest (known as Pernambuco Endemism Center) shelters a rich and endemic avifauna (Silva et al. 2004) within forest patches often surrounded by sugarcane fields. Therefore, riparian fragments may display higher, deeper and more complex ecological interactions with bird populations inhabiting the Pernambuco Endemism Center than other areas.

Woodpeckers (Picidae) are forest-dependent birds, in which the species richness is closely associated with tree cover (Ilsøe et al. 2017), being widely used as bioindicators of changes in forest structure (Mikusiński 2006, VergaraTabares et al. 2018). The Picidae is a speciose group across South America with c. 83 species (Erize et al. 2006) that display key ecological roles as builders of treecavities (excavators), which are used as nests for many species (Cockle et al. 2011, Gorman 2014). The Lineated Woodpecker Dryocopus lineatus (Linnaeus, 1766) is a tropical widespread species, ranging from Mexico to northeastern Argentina (Malekan 2011, Gorman 2014). In South America, it occurs in Argentina, Bolivia, Paraguay and throughout Brazil (Sick 1997), from the core to edges of the forest fragments (Stotz et al. 1996). Its acoustical signals are easily identifiable, especially when drilling soft-woods (drumming) for feeding on small insects, such as ants and beetles (Malekan 2011).

This report describes the recurrent seasonal occurrence of $D$. lineatus in an Atlantic Forest riparian fragment, northeastern Brazil. Because similar events occurred along years (2015, 2016 and 2017), always 
between September and October months, we suggest that the woodpecker uses the riparian fragment to refuge for breeding or escaping from the burning of sugarcane fields around its natal habitat.

\section{METHODS}

A female of D. lineatus was photographed (Fig. 1) on 23 September 2014 at $\sim 07: 50 \mathrm{~h}$ in a small riparian fragment of Atlantic Forest of the Pernambuco Endemism Center at the Santa Rita municipality, Paraíba state, northeastern Brazil. Its sex was determined by the presence of a black spot on the anterior region of the head and by the absence of a red stripe on the cheek (Erize et al. 2006). It remained $-5 \mathrm{~min}$ on a branch of a Cecropia palmata

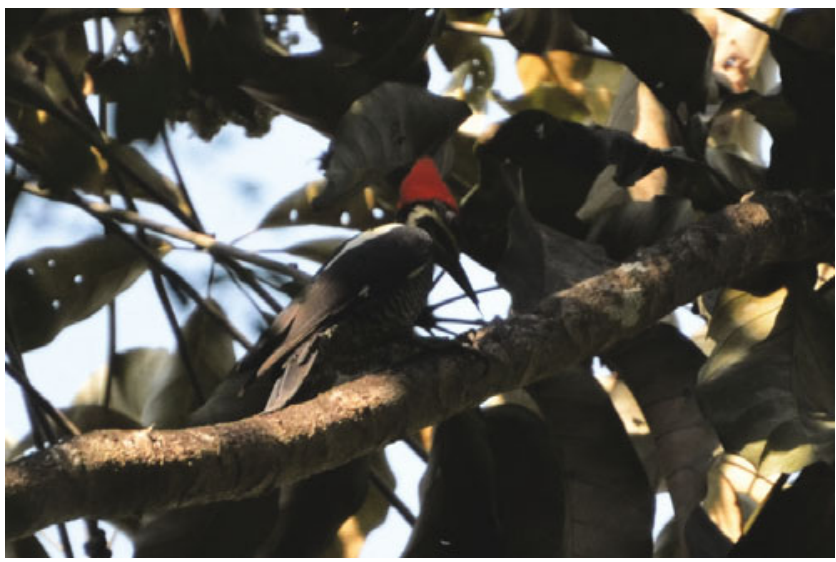

Figure 1. Female Dryocopus lineatus on a branch of Cecropia palmata in the riparian fragment of Atlantic Forest, Santa Rita (Paraíba state), northeastern Brazil. Photo author: Georgiana Pimentel. tree, foraging on small insects (ants). For this record, researchers (R.M. and G.M.P.) were at the exact point $\left(7^{\circ} 10^{\prime} 16.2^{\prime \prime} \mathrm{S}\right.$; 3500'12.9' $\left.\mathrm{W}\right)$, where local residents had previously reported sighting the bird. A playback sound with the laughing call of the species (download freely from WikiAves) was used for attracting the woodpecker, as a response to the territorial behavior (Gorman 2014). The site is a farm with 74 ha (c. $70 \%$ of forest cover) surrounded by sugarcane fields and pineapple plantations. The vegetation is typical of secondary stage composed by a high abundance of Arecaceae, Cecropiaceae and senescent trees. Tibiri River crosses the forest fragment entirely (Fig. 2A) forming microhabitats similar to floodplains and wetlands in some areas.

\section{RESULTS}

Visual and acoustical signals of the bird were recorded until October 2014 and -6 tree-cavity nests (Fig. 2B) were accounted in the area. The most common sounds were territorial calling and drumming. Sighting of the woodpeckers were reported by local residents on each consecutive year $(2015,2016$ and 2017) after the initial record in 2014, including a low-resolution video provided by one of them in 2016 (supplementary material). They also reported that the detections of the bird started in September and lasted until October, with often more than one individual observed at the same time. The authors validated the information provided by residents by showing photos of the bird (i.e. species identification) and inquiring about the record (e.g., microhabitat,
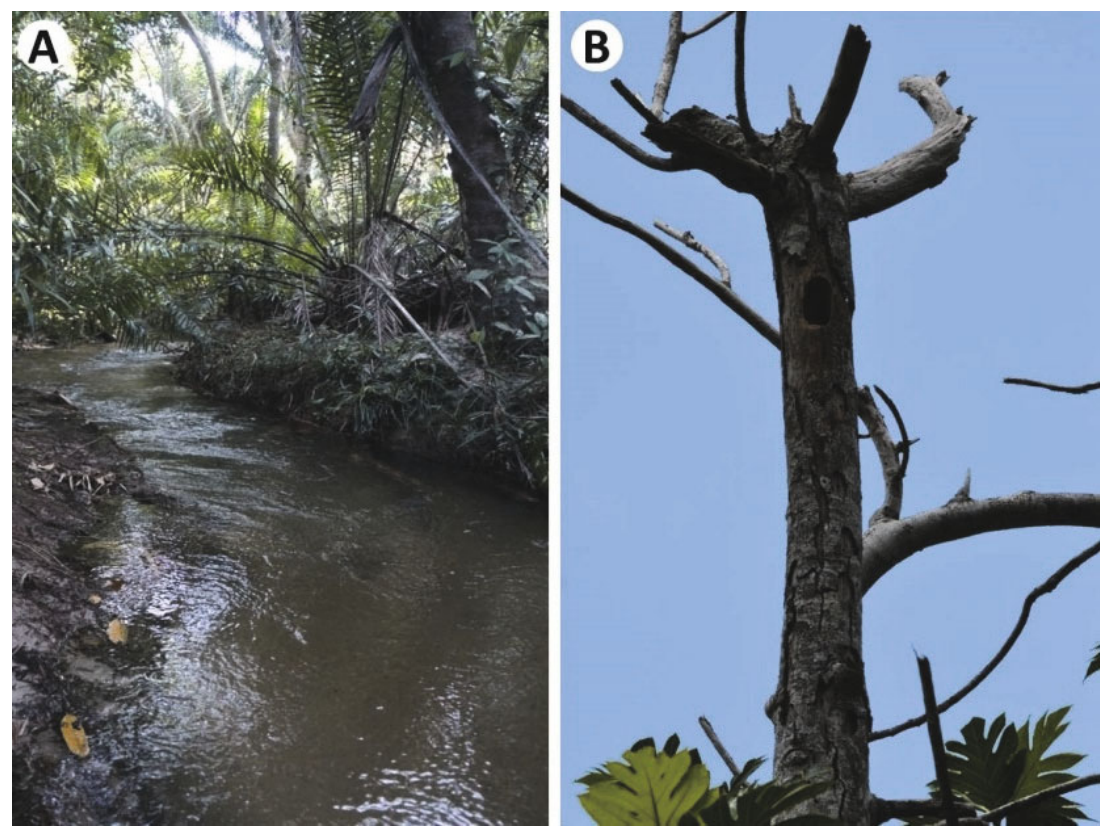

Figure 2. Tibiri River within the forest fragment in which Dryocopus lineatus was recorded (A). Tree-cavity nest of woodpecker on a dead tree (snag; B). Photo author: Rafael Menezes. 
sounds, size). It is worth mentioning that only piculet species (Picuminae, Picidae) occur in the area, with the absence of larger woodpeckers that could be confused with D. lineatus [e.g., Crimson-Crested Woodpecker Campephilus melanoleucos (Gmelin, 1788)]. The same local ancient residents claimed that the occurrence of woodpeckers is very recent in this area, because they were never seen or heard them before 2014.

\section{DISCUSSION}

The recent appearance of woodpecker can be related to well-preserved traits of the riparian fragment, as supported by occurrence of other birds [e.g., Aramides cajaneus (Statius-Muller, 1776), Porphyrio martinicus (Linnaeus, 1766)] and mammals [e.g., Lontra longicaudis (Olfers, 1818), Dasyprocta spp.) indicators of healthy environments. The high habitat heterogeneity in riparian fragment (e.g., dead tree areas, Cecropiaceae soft-wood zones, and floodplains) may also be an ecological driver for the species presence. In corroboration, recent studies have shown that Dryocopus martius (Linnaeus, 1758) uses a wide variety of forest environments in the Italian Alps (Bocca et al. 2007), D. lineatus prefers dead tree areas (snags) in Santa Fe de Antioquia/Colombia (GranadaRíos \& Mancera-Rodríguez 2015) and D. pileatus (Linnaeus, 1758) has the home range limited by the snags abundance in lowland forest of the United States (Tomasevick \& Marzluff 2018). Although the riparian fragment is relatively small, the high preservation degree coupled with habitat heterogeneity, especially dead tree areas, may have promoted the immigration of the woodpecker.

Two major hypotheses are addressed here for the woodpecker seasonal occurrence. First, D. lineatus used the riparian fragment as breeding refuge, as individuals were observed using the tree-cavity nests in 2014 (R.M., pers. obs.). The use of nests was also reported by local residents on each year (2015, 2016 and 2017) between September and October months. Different breeding periods have been documented for $D$. lineatus around the world, including March-April in Panama, April-May in Belize (Caribbean) and February-April in Trinidad and Suriname (Malekan 2011). These records reveal a short-time breeding (2-3 months), which sustain the hypothesis of breeding-related seasonal occurrence. Nevertheless, comprehensive information on biology and ecology of this species is scarce in Brazil, especially on breeding, nesting and roosting.

Secondly, the woodpecker dispersed to the riparian fragment driven by pre-harvesting sugarcane burning around its natal habitat. The region harbors large sugarcane fields and the burning practice commonly occurs over September and October. Natal habitats of woodpeckers are probably large forest remnants of legal reserve (i.e. $20 \%$ of preserved native forest within a property) belonging to sugarcane companies, which are located closer to the riparian fragment. In this sense, the bird fled from its natal habitat to the riparian fragment in order $i$ ) to avoid fire-caused injuries (Lyon \& Marzluff 1985); or $i$ i) to increase the forage on small invertebrates that escape to the forest patches nearby the fire-disturbed area (Vasconcelos et al. 2009). Fire effects on birds are species-specific and the harms increase with high-severity burning (Barlow et al. 2002, 2006).

The landscape connectivity facilitates the bird movement among nearby forest fragments (Uezu et al. 2005), and this has been recorded for large-bodied woodpeckers, such as D. martius (Gil-Tena et al. 2013) and Campephilus magellanicus (King, 1828) (Vergara et al. 2019). Recent studies have documented that woodpeckers disperse to neighboring patches mainly for foraging activities, with the movement decision influenced by the habitat quality (Vergara et al. 2015, 2019). It is likely that $D$. lineatus used the riparian vegetation as an ecological corridor for crossing from its natal habitat to the patch site. Indeed, riparian corridors have been shown effective for movement among habitats for forest specialist birds (Gillies \& Clair 2008). However, there is no study that reports seasonal movement behavior or dispersal ability for the species up to date, which raises the need of monitoring studies to understand patterns of use of forest patches by these birds.

The seasonal occurrence of $D$. lineatus in the riparian fragment suggests its use as refuge habitat, but the available information is insufficient for an unbiased definition regarding the two hypotheses on the ecological drivers operating at the population level. Further observations on breeding habits and the use of mark recapture techniques are required. Such recurrent events highlight the importance of river-edge environments for forest-dependent birds that inhabit fragmented landscapes of the Brazilian Atlantic Forest.

\section{ACKNOWLEDGEMENTS}

We thank Severino M. Oliveira (owner of site) for the access to the site, to the local residents for providing information on woodpeckers, and to the anonymous referees for the valuable suggestions for improving the manuscript. R.M. is grateful to the CAPES for Ph.D. scholarship.

\section{REFERENCES}

Anjos L.D., Volpato G.H., Lopes E.V., Serafini P.P., Poletto F. \& Aleixo A. 2007. The importance of riparian forest for the maintenance 
of bird species richness in an Atlantic Forest remnant, southern Brazil. Revista Brasileira de Zoologia 24: 1078-1086.

Barlow J., Haugaasen T. \& Peres C.A. 2002. Effects of ground fires on understorey bird assemblages in Amazonian Forests. Biological Conservation 105: 157-169.

Barlow J., Peres C.A., Henriques L.M.P., Stouffer P.C. \& Wunderle J.M. 2006. The responses of understorey birds to forest fragmentation, logging and wildfires: an Amazonian synthesis. Biological Conservation 128: 182-192.

Bocca M., Carisio L. \& Rolando A. 2007. Habitat use, home ranges and census techniques in the Black Woodpecker Dryocopus martius in the Alps. Ardea 95: 17-29.

Cockle K.L., Martin K. \& Wesolowski T. 2011. Woodpeckers, decay, and the future of cavity-nesting vertebrate communities worldwide. Frontiers in Ecology and the Environments 9: 377-382.

Erize F., Mata J.R. \& Rumboll M. 2006. Birds of South American: nonpasserines (rheas to woodpeckers). Princeton: Princeton University Press.

Gillies C.S. \& Clair C.C.S. 2008. Riparian corridors enhance movement of a forest specialist bird in fragmented tropical forest. Proceeding of the National Academy of Sciences of the United States of America 105: 19774-19779.

Gil-Tena A., Brotons L., Fortin M.J., Burel F. \& Saura S. 2013. Assessing the role of landscape connectivity in recent woodpecker range expansion in Mediterranean Europe: forest management implications. European Journal of Forest Research 132: 181-194.

Gorman G. 2014. Woodpeckers of the world: the complete guide. London: Christopher Helm.

Granada-Ríos H.D. \& Mancera-Rodríguez N.J. 2015. Aspectos ecológicos del Carpintero Dryocopus lineatus (Linnaeus, 1766) en Santa Fe de Antioquia, Colombia. Ambiente y Desarrollo 19 33-48.

Ilsøe S.K., Kissling W.D., Fjeldså J., Sandel B. \& Svenning J.C. 2017. Global variation in woodpecker species richness shaped by tree availability. Journal of Biogeography 44: 1824-1835.

Knopf F.L. \& Samson F.B. 1994. Scale perspectives on avian diversity in western riparian ecosystems. Conservation Biology 8: 669-676.

Lyon L.J. \& Marzluff J.M. 1985. Fire's effects on a small bird population, p. 16-22. In: Lotan J.E. \& Brown J.K. (eds.). Fire's effects on wildlife habitat: symposium proceedings. Missoula: Intermountain Research Station.

Malekan I.S. 2011. Lineated Woodpecker (Dryocopus lineatus). In: Schulenberg T.S. (ed.). Neotropical birds online. Ithaca: Cornell Lab of Ornithology. https://doi.org/10.2173/nb.linwoo1.01 (Access on 15 May 2018).

Mikusiński G. 2006. Woodpeckers: distribution, conservation, and research in a global perspective. Annales Zoologici Fennici 43: 86-95.
Myers N., Mittermeier R.A., Mittermeier C.G., Fonseca G.A.B. \& Kent J. 2000. Biodiversity hotspots for conservation priorities. Nature 403: 853-858.

Naiman R.J. \& Décamps H. 1997. The ecology of interfaces: riparian zones. Annual Review of Ecology and Systematics 28: 621-658.

Ramos C.C.O. \& Anjos L. 2014. The width and biotic integrity of riparian forests affect richness, abundance, and composition of bird communities. Natureza \& Conservação 12: 59-64.

Ribeiro M.C., Metzger J.P., Martensen A.C., Ponzoni F.J. \& Hirota M.M. 2009. The Brazilian Atlantic Forest: how much is left, and how is the remaining forest distributed? Implications for conservation. Biological Conservation 142: 1141-1153.

Sick H. 1997. Ornitologia Brasileira. Rio de Janeiro: Editora Nova Fronteira.

Silva J.M.C., Sousa M.C. \& Castelletti C.H.M. 2004. Areas of endemism for passerine birds in the Atlantic Forest, South America. Global Ecology and Biogeography 13: 85-92.

Stotz D.F., Fitzpatrick J.W., Parker-III T.A. \& Moskovits D.K. 1996. Neotropical birds: ecology and conservation. Chicago: University of Chicago Press.

Tomasevic J.A. \& Marzluff J.M. 2018. Space use of suburban Pileated Woodpeckers (Dryocopus pileatus): insights on the relationship between home range, core areas, and territory. Oecologia 187: $15-23$.

Uezu A., Metzger J.P. \& Vielliard J.M.E. 2005. Effects of structural and functional connectivity and patch size on the abundance of seven Atlantic Forest bird species. Biological Conservation 123: 507-519.

Vasconcelos H.L., Pacheco R., Silva R.C., Vasconcelos P.B., Lopes C.T., Costa A.N. \& Bruna E.M. 2009. Dynamics of leaf-litter arthropod fauna following fire in Neotropical woodland Savanna. PLoS ONE 4: e7762.

Vergara P.M., Saura S., Pérez-Hernández C.G. \& Soto G.E. 2015. Hierarchical spatial decisions in fragmented landscapes: modeling the foraging movements of woodpeckers. Ecological Modelling 300: 114-122.

Vergara P.M., Soto G.E., Rodewald A.D. \& Quiroz M. 2019. Behavioral switching in Magellanic Woodpeckers reveals perception of habitat quality at different spatial scales. Landscape Ecology 34: 79-92.

Vergara-Tabares D.L., Lammertink M., Verga E.G., Schaaf A.A. \& Nori J. 2018. Gone with the forest: assessing global woodpecker conservation from land use patterns. Diversity and Distributions 24: 640-651.

Associate Editor: Marcos P. Dantas. 